\title{
Effectiveness of Direct and Non-direct Investment in the Stock Market Indices
}

\author{
Monika Hadaś-Dyduch \\ University of Economics in Katowice, Katowice, Poland
}

\begin{abstract}
The article attempts to compare the direct and non-direct investment in the stock market indices. Indirect investment means a purchase of a strictly preferred particular stock index by an investor on the stock exchange. In contrast, indirect investment is the one of structured products based on stock market indices, i.e., the products of which the final result depends on the development of the stock market indices. The aim of the study is to evaluate the effectiveness of direct and non-direct investment in the stock market indices. Furthermore, the purpose of this article is an attempt to answer the following questions: Is the investment in structured products a substitute of investment in the stock market indices? Which method is more efficient, direct or indirect investment? Are structured products substitutes for traditional investments and whether they give satisfactory profits for investors? The questions may be answered by setting returns on structured products completed on 31.12.2013 in the Polish capital market. The results relating to structured products launched and completed during the period 01.01.2000-31.12.2013 in the Polish capital market were compared with the rate of return of selected stock indices. As comparison, the method of direct and indirect investments was selected for the following indices: the Hang Seng, Dow Jones, WIG, WIG 20, Hang Seng, Nikkei, and Shanghai Composite reflecting the different economies of the world and also the specifics of different investors.
\end{abstract}

Keywords: structured products, alternative investments, banking products, stock indices, the underlying instrument

\section{Introduction}

Structured products are financial instruments whose price is dependent on the value of a particular market index. Thanks to their specific design, structured products provide the investor with capital protection (full or partial) and at the same time make it possible (though not certain) to obtain income, while the payoff function is always an option. Like other investment products, the rate of return is not known ex ante. Therefore, it can be said that in the current era, structured products are complementary or may even replace the more traditional investments in stocks, bonds, and investments. They give the ability to connect traditional investing with one's hobbies and reportedly more than average profits. However, the question that must be put at this point is whether the investment is actually always profitable, giving more than average profits and favorable to the investor. Is the profit what the investor has in front of their eyes real or just an illusion? Is investing savings in

Monika Hadaś-Dyduch, Ph.D., Faculty of Economics, Department of Statistical and Mathematical Methods in Economics, University of Economics in Katowice, Poland.

Correspondence concerning this article should be addressed to Monika Hadaś-Dyduch, Faculty of Economics, Department of Statistical and Mathematical Methods in Economics, University of Economics in Katowice, ul. 1 Maja 50, 40-287 Katowice, Poland. E-mail: monika.dyduch@ue.katowice.pl. 
investment products really worth it? Is it a worthwhile investment decision? Do your dreams of a gain of settlement investment remain unfulfilled or unrealized? Is the investment in structured products a substitute for real-life investing in stock market indices?

The questions may be answered by setting returns on structured products ended on 31.12.2013 in the Polish capital market. The results relating to structured products launched and completed during the period from 01.01.2000 to 31.12.2013 in the Polish capital market were compared with the rate of return of selected stock indices. As comparison, the method of direct and indirect investments was selected for the following indices: the Hang Seng, Dow Jones, WIG, WIG 20, Hang Seng, Nikkei, and Shanghai Composite.

\section{Literature Review}

The results of the research presented in this article are fully copyright, partially based on the previous studies concerning this issue (Hadaś-Dyduch, 2013a, 2013b, 2013c, 2013d, 2013e, 2013f, 2013g, 2014a, 2014b, $2014 \mathrm{c}, 2014 \mathrm{e})$. The calculation is based on data of the basic parameters measurable on structured products. The data necessary to carry out the research presented in the article were obtained from financial portals banks and financial institutions issuing structured products.

Definition and status of structured products in Poland are presented in the report of financial supervision.

\section{Research Methods}

The questions posed in the article may be answered by setting returns on structured products ended on 31.12.2013 in the Polish capital market. The results relating to structured products launched and completed during the period from 01.01.2000 to 31.12.2013 in the Polish capital market were compared with the rate of return of selected stock indices. As comparison, the method of direct and indirect investments was selected for the following indices: the Hang Seng, Dow Jones, WIG, WIG 20, Hang Seng, Nikkei, and Shanghai Composite.

The analysis was based on 802 structured products with different legal forms whose base index was based on the index or basket of stock indices. Sixty-three bank securities, 39 structured certificates 23 closed-end investment funds, seven foreign funds, 108 structured deposits, 51 structured bonds, 483 investment policies, and 28 life insurances with the insurance capital fund were investigated.

Most of the studies which were included structured products (260 products) began in 2009 and the least 2 products in 2000 and 2013 (Table 1). In contrast, most of structured products (560) were completed in 2012 and the least (4 products) in 2004 year (Table 2).

The study also recognizes structured products with different periods of investment. Most structured products were found for a period of 35 months (Table 3).

Table 1

Number of Structured Products Launched in Each Year of the Research Period

\begin{tabular}{lllllllllllllll}
\hline Year* & 2000 & 2001 & 2002 & 2003 & 2004 & 2005 & 2006 & 2007 & 2008 & 2009 & 2010 & 2011 & 2012 & 2013 \\
\hline Quantity** & 2 & 6 & 6 & 5 & 6 & 9 & 22 & 73 & 171 & 242 & 184 & 63 & 11 & 2 \\
\hline
\end{tabular}

Notes. ${ }^{*}$ Number of structured products launched and completed at the same time to 31.12.2013 year; $* *$ Start year structured product.

For each of the 802 structured products, gross return per month and year were designated, in order to compare the rate of return on a direct investment in the stock market index. 
Comparative analysis of indirect and direct method is illustrated by the indices: Dow Jones, WIG, WIG 20, Hang Seng, Nikkei, and Shanghai Composite. Data on the indices were downloaded from the archives of the relevant stock exchanges.

Structured products completed in the years from 2000 to 2013 reached a gross rate of return on an annual basis in the range from $-12.29 \%$ to $38.58 \%$. The average gross rate of return of structured products which were completed in the years from 2000 to 2013 was $2.55 \%$ per year (Table 4 ).

Table 2

Number of Structured Products in Each Year of Completed Study Period

\begin{tabular}{llllllllllll}
\hline Year* & 2003 & 2004 & 2005 & 2006 & 2007 & 2008 & 2009 & 2010 & 2011 & 2012 & 2013 \\
\hline Quantity & 2 & 2 & 6 & 6 & 13 & 7 & 38 & 106 & 200 & 270 & 152 \\
\hline
\end{tabular}

Note. * End year a structured product.

Table 3

Number of Completed Structured Products for a Specified Duration of the Product (in Months)

\begin{tabular}{llllll}
\hline $\begin{array}{l}\text { Duration of product } \\
\text { (in months) }\end{array}$ & $\begin{array}{l}\text { The number of } \\
\text { completed products }\end{array}$ & $\begin{array}{l}\text { Duration of product } \\
\text { (in months) }\end{array}$ & $\begin{array}{l}\text { The number of } \\
\text { completed products }\end{array}$ & $\begin{array}{l}\text { Duration of product } \\
\text { (in months) }\end{array}$ & $\begin{array}{l}\text { The number of } \\
\text { completed products }\end{array}$ \\
\hline 3 & 1 & 26 & 1 & 39 & 1 \\
6 & 21 & 28 & 4 & 41 & 1 \\
9 & 11 & 29 & 4 & 42 & 17 \\
10 & 1 & 30 & 16 & 44 & 1 \\
12 & 116 & 34 & 8 & 45 & 1 \\
18 & 24 & 36 & 231 & 48 & 135 \\
24 & 182 & 37 & 2 & 60 & 17 \\
\end{tabular}

Table 4

Basic Statistics Presenting a Series of Tax Return for Completed Structured Products in the Years From 2000 to 2013

\begin{tabular}{lllc}
\hline Statistics & Value of statistics & Statistics & Value of statistics \\
\hline Average & $2.55 \%$ & Median & $0.37 \%$ \\
Standard error of mean & 0.18 & Minimum & $-12.29 \%$ \\
Dominant & $0.00 \%$ & Maximum & $38.58 \%$ \\
Standard deviation & 5.22 & & \\
\hline
\end{tabular}

Table 5

Percentiles Series Presenting Gross Return Per Month of Structured Products Completed in the Years From 2000 to 2013

\begin{tabular}{lllcll}
\hline Percentile & Value of precentile & Percentile & Value of precentile & Percentile & Value of precentile \\
\hline 10 & $0 \%$ & 60 & $1.66 \%$ & 20 & $0 \%$ \\
25 & $0 \%$ & 75 & $4.01 \%$ & 30 & $0 \%$ \\
40 & $0 \%$ & 90 & $10.00 \%$ & 50 & $0.37 \%$ \\
& & 80 & $5.12 \%$ & 70 & $3.23 \%$ \\
\hline
\end{tabular}

Frequently finished products had a gross return of $0 \%$ per year, including 292 structured products in the period, which accounted for $36.4 \%$ of the products, for which gross rate of return on the investment's completion has been designated. 
Seventy-five percent completed structured products ended up with reaching a gross rate of return per year of at most $4.01 \%$ (Table 5 ).

\section{Negative Gross Rate of Return}

All structured products of $6.97 \%$ in that period were completed with a negative rate of return (Hadaś-Dyduch, 2013a, 2014a, 2014b, 2014c, 2014e). The value of $-10 \%$ per year among the negative returns dominated (Table 6). In addition, 50\% of return of structured products which ended with a negative rate had a rate of return of $-4.72 \%$ at most (Table 7 ).

Table 6

Basic Statistics Series Presenting Gross Negative Return of Completed Structured Products in the Years From 2000 to 2013

\begin{tabular}{llll}
\hline Statistics & Value of statistics & Statistics & Value of statistics \\
\hline Average & $-5.66 \%$ & Median & $-12.29 \%$ \\
Standard error of mean & 0.45 & Minimum & $-0.52 \%$ \\
Dominant & $-4.72 \%$ & Maximum & $-10 \%$ \\
Standard deviation & 3.38 & & \\
\hline
\end{tabular}

Table 7

Percentiles Series Presenting Gross Negative Return for the Year of Completed Structured Products in the Years From 2000 to 2013

\begin{tabular}{llllll}
\hline Percentile & Value of precentile & Percentile & Value of precentile & Percentile & Value of precentile \\
\hline 10 & $-10 \%$ & 60 & $-3.33 \%$ & 20 & $-10 \%$ \\
25 & $-10 \%$ & 75 & $-3.04 \%$ & 30 & $-8.57 \%$ \\
40 & $-7 \%$ & 90 & $-1.59 \%$ & 50 & $-4.72 \%$ \\
& & 80 & $-2.52 \%$ & 70 & $-3.33 \%$ \\
\hline
\end{tabular}

Seventy-five percent structured products completed with a negative rate of return ended up with reaching a gross rate of return per year of at most $-3.04 \%$ (Table 7).

\section{Positive Rate of Return Before Tax}

The products of $56.54 \%$ resulted in achieving positive returns. Among them, the rate of return of $10 \%$ per year dominated (Hadaś-Dyduch, 2013d, 2013e, 2013f, 2013g, 2014a). About 50\% of completed structured products with a positive rate of return on investment settlement resulted in achieving a rate of return at least at the level of $3.36 \%$ per year (Table 8 ).

Seventy-five percent of products completed with a positive rate of return on structured products resulted in reaching a gross rate of return per year of at most $8.33 \%$ (Table 9).

Table 8

Basic Statistics Presenting a Series of Positive Gross Returns of Structured Products Completed in the Years From 2000 to 2013

\begin{tabular}{llll}
\hline Statistics & Value of statistics & Statistics & Value of statistics \\
\hline Average & $5.21 \%$ & Median & $0.01 \%$ \\
Standard error of mean & 0.24 & Minimum & $38.58 \%$ \\
Dominant & $3.36 \%$ & Maximum & $10 \%$ \\
Standard deviation & 5.21 & & \\
\hline
\end{tabular}


Table 9

Percentiles Series Presenting Gross Negative Return for the Year Ended in the Years From 2000 to 2013 of Structured Products

\begin{tabular}{llll}
\hline Percentile & Value of precentile & Percentile & Value of precentile \\
\hline 10 & $0.33 \%$ & 20 & $1.09 \%$ \\
25 & $1.44 \%$ & 30 & $1.77 \%$ \\
40 & $2.59 \%$ & 50 & $3.36 \%$ \\
60 & $4.58 \%$ & 70 & $6.21 \%$ \\
75 & $8.33 \%$ & 80 & $9.63 \%$ \\
90 & $12.51 \%$ & & \\
\hline
\end{tabular}

\section{Research Results and Analysis}

Preliminary results of a study on the rate of return achieved by the structured products whose underlying index was based on stock market indices are presented in the following. This chapter focuses on the comparison of return on a direct investment in the index with no direct investment, which is an investment in a structured product based on the stock index or basket of indices.

The results of the study and the attempt to answer the question were divided into several sections, depending on the duration of the investment. Time is a key element in determining the gain or loss on investment. For a comparative analysis, the indices: Dow Jones, WIG, WIG 20, Hang Seng, Nikkei, and Shanghai Composite were selected. The aim was to reflect the return on structured products in different world economies and the comparison of direct and non-direct method in the scale of the global market.

\section{Possible Maximum and Minimum Rate of Return in the Considered Period}

With non-direct investment in stock market indices, i.e. through structured products based on stock market indices completed in the years from 2000 to 2013 in the Polish capital market, it could achieve a gross rate of return per year ranging from $-12.29 \%$ to $3.215 \%$ (Hadaś-Dyduch, 2013a, 2013b, 2013c, 2013d, 2013e, 2013f, 2013g, 2014a, 2014b, 2014c, 2014e).

\section{Worst Non-direct Investment}

The lowest rate of return, i.e. $-12.29 \%$ per year, was reached by the structured product "Certificate of Brazilian Express", whose investment lasted for 36 months. The project was started on 13.11.2010 and ended on 12.11.2013. It was a structured product based on the iShares MSCI Brazil Index Fund.

As shown by the data in Table 10, during the period of direct investment in the iShares MSCI from 13.11.2010 to 12.11.2013, Brazil Index Fund was finished with a loss. The loss would be $11.87 \%$ per year (Table 10). Thus, both the base index of investment in structured product "Certificate of Brazilian Express" and the direct investment in structured product ended up at a significant loss.

Table 10

Rate of Return of Ishares MSCI Brazil Index Fund for the Period From 15.11.2010 to 12.11.2013

\begin{tabular}{ll}
\hline Data reading according to the opening & i-Shares MSCI Brazil Index Fund \\
\hline 2010.11 .15 & 70.16 \\
2013.11 .12 & 45.18 \\
Rate of return & $-35.61 \%$ \\
\hline
\end{tabular}

Moreover, the investment in the WIG and the Dow Jones Industrial would make a profit at the level of 
$4.2 \%$ and $13.64 \%$ per year (Table 11 ). In any case, direct investment would not be worse than the non-direct investment.

Table 11

Quotations Index for the Period From 15.11.2010 to 12.11.2013

\begin{tabular}{|c|c|c|c|c|c|c|}
\hline \multirow{2}{*}{$\begin{array}{l}\text { Data reading } \\
\text { according to } \\
\text { the opening }\end{array}$} & \multicolumn{6}{|c|}{ Index } \\
\hline & WIG & WIG 20 & Hang Seng & $\begin{array}{l}\text { Dow Jones } \\
\text { Industrial }\end{array}$ & Nikkei & $\begin{array}{l}\text { Shanghai } \\
\text { Composite }\end{array}$ \\
\hline 2010.11 .15 & $47,455.78$ & $2,733.86$ & $24,371.77$ & $11,194.02$ & $9,782.11$ & $2,984.87$ \\
\hline 2013.11 .12 & $53,430.78$ & $2,516.63$ & $23,051.76$ & $15,773.15$ & $14,289.87$ & $2,126.77$ \\
\hline Rate of return & $12.59 \%$ & $-7.95 \%$ & $-5.42 \%$ & $40.91 \%$ & $46.08 \%$ & $-28.75 \%$ \\
\hline
\end{tabular}

\section{Best Non-direct Investment}

The highest rate of return of completed structured products during the period from 2000 to 2013 based on the market indices was reached by a structured product called "Ark Global Index 2007", which was issued by "Bank Zachodni WBK AIB Towarzystwo Funduszy Inwetycyjnych". The product was based on a basket of indices S \& P 500, DJ Eurostoxx 50, and Nikkei 225. At the end of the structured product investments, it should have paid a higher value of $100 \%$, as a result of the cart or guaranteed rate of return. The project was a success. Gross rate of return of the total investment amounted to $154.33 \%$, which is $38.58 \%$ per year. The project lasted 48 months, i.e. from 29.12.2003 to 28.12.2007.

Investing for a period of 48 months in the stock indices, the following rate of return on an annual basis would be obtained: $42.42 \%$ for the WIG, $30.39 \%$ WIG $20,30.27 \%$ for the Hang Seng, $7.36 \%$ for the Dow Jones Industrial, $11.86 \%$ for the Nikkei, $63.12 \%$ for the Shanghai Composite, $8.76 \%$ for the S \& P, and $15.14 \%$ for the DJ Eurostoxx 50 (Table 12). Thus, in the investment, portfolio (direct investment in the stock market indices) identical with the index underlying an analyzed structured product, consisting of $1 / 3$ of the indices of the S \& P 500, DJ Eurostoxx 50, and Nikkei 225 average rate of return of the portfolio (direct investment in the stock market indices) would be $11.92 \%$ per year. Therefore, no direct investment in the index, i.e. an investment in structured product "Arka Global Index 2007" would be more beneficial for the investor. The investor could gain $26.66 \%$ more from investment in structured product than a direct investment in a portfolio of S \& P500 index, DJ Eurostoxx 50, and Nikkei 225.

Table 12

Rate of Return Indices for the Period from 29.12.2003 to 28.12.2007

\begin{tabular}{|c|c|c|c|c|c|c|c|c|}
\hline \multirow{2}{*}{$\begin{array}{l}\text { Data reading } \\
\text { according to } \\
\text { the opening }\end{array}$} & \multicolumn{8}{|c|}{ Index } \\
\hline & WIG & WIG 20 & Hang Seng & $\begin{array}{l}\text { Dow Jones } \\
\text { Industrial }\end{array}$ & Nikkei 225 & $\begin{array}{l}\text { Shanghai } \\
\text { Composite }\end{array}$ & S\&P 500 & $\begin{array}{l}\text { DJ } \\
\text { Eurostoxx } 50\end{array}$ \\
\hline 29.12 .2003 & $20,892.74$ & $1,581.84$ & $12,443.56$ & $10,321.35$ & $10,454.69$ & $1,509.28$ & $1,095.89$ & $2,743.4$ \\
\hline 28.12.2007 & $56,342.48$ & $3,504.62$ & $27,511.54$ & $13,361.23$ & $15,413.37$ & $5,320.01$ & $1,479.83$ & $4,404.64$ \\
\hline Rate of return & $169.67 \%$ & $121.55 \%$ & $121.09 \%$ & $29.45 \%$ & $47.43 \%$ & $252.49 \%$ & $35.03 \%$ & $60.55 \%$ \\
\hline
\end{tabular}

Legal form and return. Structured products completed in Poland during the year from 1.01.2000 to 31.12.2013 adopt one of the forms: bank securities, structured certificates Closed Investment Fund, foreign fund, investment banking, structured notes, investment policy, and life insurance unit-linked.

Average rate of return. The highest average rate of return achieved in the form of structured products 
structured certificates $7.88 \%$ gross per annum and the lowest in the form of investment policy $-1.09 \%$ gross per annum (Table 13).

Table 13

Average Rate of Return (Gross Per Year) Achieved Through Structured Products in Different Legal Forms

\begin{tabular}{ll}
\hline Legal forms & Rate of return \\
\hline bank securities & $2.53 \%$ \\
structured certificates & $7.88 \%$ \\
Closed Investment Fund & $6.50 \%$ \\
foreign fund & $6.86 \%$ \\
investment & $4.54 \%$ \\
structured bond & $5.92 \%$ \\
investment policy & $1.09 \%$ \\
life insurance unit-linked & $2.32 \%$ \\
\hline
\end{tabular}

Compared to the average rates of return achieved by the WIG 20, WIG, Hang Seng, Dow Jones Industrial, Nikkei, and Shanghai Composite, non-direct investment, excluding investments in investment policy, was more favorable for each item (Table 14). Only the Dow Jones Industrial Index reached a rate of return that exceeds the lowest return gross achieved in non-direct investment.

Table 14

Average Rate of Return Achieved by the Stock Market Indices in the Period From 1.01.2000 to 31.12.2013

\begin{tabular}{ll}
\hline Index & Average rate of return \\
\hline WIG 20 & $0.02 \%$ \\
WIG & $0.04 \%$ \\
Hang Seng & $0.04 \%$ \\
Dow Jones Industrial & $1.48 \%$ \\
Nikkei & $0.12 \%$ \\
Shanghai Composite & $0.04 \%$ \\
\hline
\end{tabular}

Lowest rate of return. As previously mentioned, the return of investment in indirect investment ranged from $-12.29 \%$ to $3.215 \%$. Depending on the legal form of a structured product, the minimum rate of return ranged from $-12.29 \%$ to $0.14 \%$ (Table 15 ).

Table 15

Lowest Rate of Return (Gross Per Year) Achieved Through Structured Products in Different Legal Forms

\begin{tabular}{lc}
\hline Legal forms & Rate of return \\
\hline bank securities & $0.00 \%$ \\
structured certificates & $-12.29 \%$ \\
Closed Investment Fund & $-1.43 \%$ \\
foreign fund & $0.14 \%$ \\
investment & $0.00 \%$ \\
structured bond & $-0.67 \%$ \\
investment policy & $-10.00 \%$ \\
life insurance unit-linked & $-3.16 \%$ \\
\hline
\end{tabular}


Investment in bank securities reached the lowest rate of return of $0 \%$ per year. Structured products in the form of bank securities, culminating with zero rate of return, accounted for $30.2 \%$ of total bank securities completed in the period (Table 16).

Table 16

Gross Rate of Return Achieved by the Bank Securities

\begin{tabular}{|c|c|}
\hline Gross rate of return per year & Bank interest securities \\
\hline $0.00 \%$ & $30.16 \%$ \\
\hline $0.02 \%$ & $4.76 \%$ \\
\hline $0.05 \%$ & $1.59 \%$ \\
\hline $0.10 \%$ & $4.76 \%$ \\
\hline $0.13 \%$ & $1.59 \%$ \\
\hline $0.20 \%$ & $3.17 \%$ \\
\hline $0.34 \%$ & $1.59 \%$ \\
\hline $0.36 \%$ & $4.76 \%$ \\
\hline $0.75 \%$ & $1.59 \%$ \\
\hline $0.87 \%$ & $1.59 \%$ \\
\hline $2.05 \%$ & $1.59 \%$ \\
\hline $2.34 \%$ & $1.59 \%$ \\
\hline $2.72 \%$ & $1.59 \%$ \\
\hline $3.05 \%$ & $1.59 \%$ \\
\hline $3.33 \%$ & $1.59 \%$ \\
\hline $3.36 \%$ & $3.17 \%$ \\
\hline $3.82 \%$ & $3.17 \%$ \\
\hline $4.01 \%$ & $1.59 \%$ \\
\hline $4.05 \%$ & $1.59 \%$ \\
\hline $4.25 \%$ & $1.59 \%$ \\
\hline $4.58 \%$ & $3.17 \%$ \\
\hline $4.60 \%$ & $3.17 \%$ \\
\hline $4.86 \%$ & $1.59 \%$ \\
\hline $4.87 \%$ & $1.59 \%$ \\
\hline $5.00 \%$ & $1.59 \%$ \\
\hline $5.52 \%$ & $3.17 \%$ \\
\hline $6.75 \%$ & $1.59 \%$ \\
\hline $7.57 \%$ & $1.59 \%$ \\
\hline $8.88 \%$ & $1.59 \%$ \\
\hline $9.01 \%$ & $1.59 \%$ \\
\hline $10.00 \%$ & $1.59 \%$ \\
\hline $10.32 \%$ & $1.59 \%$ \\
\hline $18.75 \%$ & $1.59 \%$ \\
\hline
\end{tabular}

Among the structured products in the form of bank securities which were completed with a zero rate of return, products based on the WIG 20 (Table 17) dominated.

The conclusion of comparing the selected bank securities (Table 18) returns with the possible obtainable rates of return on direct investment is:

- First product of non-direct investment was more favorable, because the investor did not lose anything. 
However, in case of a direct investment in the index WIG 20, the loss is $5.74 \%$ of the invested capital over the period of the investment (Table 19). The loss would be $3.83 \%$ per year;

- Second product of non-direct investment was more favorable, because the investor did not lose anything. However, in case of a direct investment in the RTS index the loss might be $24.99 \%$ of the invested capital over the period of the investment (Table 20). Thus, the loss would be $12.49 \%$ per year.

Table 17

Baskets in Completed Structured Products in the Form of Bank Securities With 0\% Rate of Return

\begin{tabular}{lc}
\hline Basket & Percentage of products \\
\hline WIG20 & $44.44 \%$ \\
RDX USD & $5.56 \%$ \\
FTSE EPRA/NAREIT Euro Zone Index - EPEU & $5.56 \%$ \\
Dow Jones Euro Stoxx 50 Index & $5.56 \%$ \\
Indeks RDX & $5.56 \%$ \\
DJ Euro Stoxx 50, DJ Euro Stoxx Select Dividend 30 & $16.67 \%$ \\
DJ Euro Stoxx 50 & $16.67 \%$ \\
\hline
\end{tabular}

Table 18

Indirect Bank Securities Selected for Detailed Analysis

\begin{tabular}{llll}
\hline The issuer of the product & Data in beginning investment & Data completion of the investment & Basket \\
\hline Bank BPH & 5.06 .2010 & 5.12 .2011 & WIG 20 \\
Bank Millennium & 5.03 .2011 & 4.03 .2013 & RTS \\
\hline
\end{tabular}

Table 19

Data for WIG 20 Index

\begin{tabular}{ll}
\hline Data reading according to the opening & The value of the index \\
\hline 5.06 .2010 & 2417.86 \\
5.12 .2011 & 2279.03 \\
\hline
\end{tabular}

Table 20

Data for RTS Index

\begin{tabular}{ll}
\hline Data reading according to the opening & The value of the index \\
\hline 5.03 .2011 & 2012.68 \\
4.03 .2013 & 1509.80 \\
\hline
\end{tabular}

Highest rate of return. As previously mentioned, the return of investment in indirect investments ranged from $-12.29 \%$ to $3.215 \%$. Depending on the legal form of a structured product, the maximum rate of return ranged from $14.94 \%$ to $38.58 \%$ (Table 21 ).

Structured product in the form of a life insurance unit-linked, which in this form has reached the maximum profit, was based on an index SPDR Gold. The project lasted 30 months. The investment period was from 9.10.2010 to 29.04.2013.

Investing directly in an index SPDR Gold the investor would gain $8.07 \%$ in the investment, which is $3.23 \%$ per year (Table 22). Thus, non-direct investment was more favorable, because the investor gained $14.94 \%$ per annum. 
Table 21

Greatest Rate of Return (Gross Per Year) Achieved Through Structured Products, Depending on the Legal Form

\begin{tabular}{ll}
\hline Legal forms & Rate of return \\
\hline bank securities & $18.75 \%$ \\
structured certificates & $24.00 \%$ \\
closed investment fund & $38.58 \%$ \\
foreign fund & $18.66 \%$ \\
investment & $18.62 \%$ \\
structured bond & $18.00 \%$ \\
investment policy & $30.45 \%$ \\
life insurance unit-linked & $14.94 \%$ \\
\hline
\end{tabular}

Table 22

Data for SPDR Gold Index

\begin{tabular}{ll}
\hline Data reading according to the opening & The value of the index \\
\hline 29.10 .2010 & 131.48 \\
29.04 .2013 & 142.09 \\
\hline
\end{tabular}

\section{Conclusions}

The article attempts to compare the direct and non-direct investment in the stock market indices. Indirect investment means a purchase of a strictly preferred particular stock index by an investor on the stock exchange. In contrast, indirect investment is the one of structured products based on stock market indices, i.e., the products of which the final result depends on the development of the stock market indices. The analysis shows that it is impossible to explicitly answer the question, because at certain times the direct investment would seem to be more appropriate than a non-direct.

However, knowledge of archival rates of return allows the estimation of the specified error of the estimated future value of investments using a variety of methods including (Hadaś-Dyduch, 2014d).

\section{References}

Hadaś-Dyduch, M. (2013a). Bankowe papiery wartościowe strukturyzowane (Banking structured sectured). Retrieved from http://yadda.icm.edu.pl/yadda/element/bwmeta1.element.ekon-element-000171249203

Hadaś-Dyduch, M. (2013b). Efektywność inwestycji w Bankowe Papiery Wartościowe (Effectiveness of investment in bank securities). Retrieved from http://bazekon.icm.edu.pl/bazekon/element/bwmeta1.element.ekon-element-000171234535

Hadaś-Dyduch, M. (2013c). Inwestycje alternatywne na polskim rynku kapitałowym (Alternative investments on the Polish capital market). Retrieved from http://bazekon.icm.edu.pl/bazekon/element/bwmeta1. element.ekon-element-000171257757

Hadaś-Dyduch, M. (2013d). Ranking produktów strukturyzowanych wyemitowanych na polskim rynku finansowym w latach 2001-2010 (Ranking structured products issued on the Polish financial market in 2001-2010). Zeszyty Naukowe Wyższej Szkoły Bankowej we Wrocławiu, Zastosowanie metod ilościowych w naukach ekonomicznych, 2(34), 187-200.

Hadaś-Dyduch, M. (2013e). Stopa bezrobocia jako instrument bazowy lokaty strukturyzowanej (The unemployment rate as the underlying structured deposit). Retrieved from http://bazekon.icm.edu.pl/bazekon/element/bwmeta1.element. ekon-element-000171272721

Hadaś-Dyduch, M. (2013f). Szacowanie efektywności wybranej strategii inwestowania w produkty strukturyzowane na polskim rynku kapitałowym (Estimating the effectiveness of the chosen strategy of investing in products structured in the Polish capital market). Retrieved from http://www.wneiz.pl/nauka_wneiz/frfu/63-2013/FRFU-63-169.pdf 
Hadaś-Dyduch, M. (2013g). Współczesne formy gospodarowania kapitałem wobec ekonomicznych zjawisk kryzysowych (Contemporary form of management capital to economic crisis phenomena). Retrieved from http://yadda.icm.edu.pl/yadda/element/bwmeta1.element.ekon-element-000171254811?q=019b3434-712c-4d4e-b141-c5b23 a7503c5\$9\&t=IN_PAGE

Hadaś-Dyduch, M. (2014a). Charakterystyka rynku produktów strukturyzowanych oferowanych w formie Funduszy Inwestycyjnych Zamkniętych zakończonych w latach 2000-2013 (Description of the market of structured products offered in the form of closed-end investment funds which ended in the years 2000-2013). Retrieved from http://piu.org.pl/public/upload/ibrowser/Wiadomosci\%20Ubezpieczeniowe/WU\%202-2014.pdf

Hadaś-Dyduch, M. (2014b). Efektywność alternatywnych inwestycji kapitałowych na przykładzie polisy inwestycyjnej (Effectiveness of alternative investment capital on example investment policy). Retrieved from http://yadda.icm.edu.pl/yadda/element/bwmeta1.element.ekon-element-000171284295?q=019b3434-712c-4d4e-b141-c5b23 a $7503 \mathrm{c} 5 \$ 1 \& \mathrm{qt}=\mathrm{IN} \_$PAGE

Hadaś-Dyduch, M. (2014c). Koncepcja oceny efektywności finansowej inwestycji w certyfikaty dyskontowe na przykładzie Lotos SA. (The concept of assessing the effectives of financial and investment certificates discount on the example of LOTOS SA). Retrieved from http://yadda.icm.edu.pl/yadda/element/bwmeta1.element.ekon-element-000171286701?q=019b3434-712c-4d4e-b141-c5b23 a7503c5\$2\&qt=IN_PAGE

Hadaś-Dyduch, M. (2014d). Non-classical algorithm for time series prediction of the range of economic phenomena with regard to the interaction of financial market indicators. Chinese Business Review, 13(4), 221-231.

Hadaś-Dyduch, M. (2014e). The market for structured products in the context of inflation. Retrieved from http://pliki.konferencjazakopianska.pl/proceedings.html 